\title{
Ayat-ayat Al-Quran Berkaitan Bisnes: Satu Kupasan Buku
}

\author{
The Commercial-Theological Terms in The Koran
}

\author{
Siti Anisah Atan@ Yaakub \\ Fakulti Pengurusan Teknologi dan Perniagaan, Universiti Tun Hussein Onn Malaysia, \\ 86400 Parit Raja, Batu Pahat, Johor, Malaysia \\ Tel: +607-4533903 E-mel: anisah@uthm.edu.my
}

\begin{abstract}
Abstrak
Al-Quran adalah rujukan utama ajaran Islam, mengandungi prinsip-prinsip asas untuk setiap permasalahan dalam kehidupan manusia.Untuk mendapat pandangan Islam tentang bisnes, penulis ingin mengetahui terlebih dahulu apa AlQuran kata mengenai bisnes. Beberapa rujukan telah dibuat, termasuk pencarian dalam indeks terjemahan Al-Quran, penulis tidak menemukan analisa yang sebegitu lengkap seperti yang terdapat di dalam buku The CommercialTheological Terms in The Koran oleh Charles C. Torrey. Buku ini membahagikan ayat-ayat Al-Quran yang berkaitan bisnes kepada 2 kategori. Ayat-ayat yang membicarakan dunia bisnes sebenar dan ayat-ayat Al-Quran yang menggunakan istilah-istilah dunia bisnes untuk menerangkan teologi Islam. Ternyata banyak sekali ayat Al-Quran berbicara tentang dunia bisnes sebenar, tetapi lagi banyak menggunakan istilah-istilah dunia bisnes untuk teologi Islam yang mana bilangannya menghampiri 370 ayat. Walau pun buku ini mendapat kritikan kerana penulisnya seorang orientalis Yahudi, namun analisanya terhadap ayat-ayat berkaitan bisnes sangat lengkap dan terperinci.
\end{abstract}

Kata Kunci: Bisnes dalam Al-Quran; Istilah bisnes dalam Al-Quran; Perniagaan dalam AlQuran; Istilah Komersial Al-Quran; Islam dan Perniagaan

\begin{abstract}
The Qur'an is the primary reference in Islam. It contains the basic principles for all matters in human life. In order to get an idea of what Islam has to say about business, one has first
\end{abstract}

to understand what the Qur'an says about business. I have consulted many references on business terms in the Qur'an and I have found no other reference that is more comprehensive in analyzing business terminologies in the Qur'an than The Commercial-Theological Terms in the Koran by Charles C. Torrey. Torrey's book divided the Qur'anic verses concerning business into two categories: verses that truly deal with business issues, and verses that simply utilize business terms in order to explain the Islamic theology. A study of Torrey's book reveals that there are many verses in the Qur'an dealing with actual business, but there are even more verses (around 370 verses) that appropriate business terminologies for theological purposes. While this book may be criticized by the Muslim world because the author is a Jewish orientalist, nonetheless, one cannot deny the comprehensiveness of the book in analyzing those business terms contained therein in the Qur'anic text. This paper is about an exposé of the book and its contribution to the Muslim world.

Keywords: Business in the Qur'an; Qur'anic business terminologies; Commercial terms in the Qur'an

\section{Pengenalan}

Al-Quran merupakan rujukan utama ajaran Islam. Ia mengandungi prinsip-prinsip dan panduan asas dalam pelbagai aspek kehidupan manusia bermula dari hal-hal akidah dan ketuhanan sehinggalah permasalahan sosial, ekonomi dan politik. Maka, apa-apa perkara yang ingin dikupas dari perspektif Islam, tidak boleh tidak mesti merujuk Al-Quran. 
Dalam usaha untuk menulis mengenai pandangan Islam terhadap bisnes, penulis terlebih dahulu ingin menulis mengenai apa Al-Quran kata mengenai bisnes dengan menyenaraikan ayat-ayat Al-Quran tentang bisnes. Dengan menggunakan terjemahan AlQuran dalam Bahasa Inggeris bertajuk The Holy Quran : English Translation of The Meanings and Commentary oleh Abdullah Yusuf Ali (1994), penulis telah menyemak indeks untuk mencari istilah yang ada kaitan dengan dunia bisnes. Berikut adalah istilah-istilah bisnes yang ditemukan:

\begin{tabular}{lc} 
Istilah & Ayat Al-Quran \\
Commerce that will never fail & $35: 29$ \\
Fraud & $3: 1-6$ \\
Loan, beautiful, to god & $2: 245$, \\
\multicolumn{3}{c}{ 57:11, 18, 64:17, $78: 20$} \\
Measure and weight, give full & $17: 35 ;$ \\
& $83: 1-3$ \\
Traffic and trade & $4: 29$ \\
Usury & $2: 275-$
\end{tabular}

276, 2:278-280, 3: 130

Selain indeks, penulis telah merujuk buku oleh Malahayati (2010). Pada topik Al-Quran bicara bisnes, buku ini memfokus pada istilahistilah bisnes seperti tijarah, bai', tadayantum, dan isytara. Dalam tulisan Mohammad Shafi (2000) menyatakan bahawa Al-Quran tidak menggunakan perkataan bahasa Arab klasik yang tepat sepadan dengan perkataan bisnes, sebaliknya menggunakan istilah-istilah yang tidak langsung untuk membicarakan konsep bisnes seperti isytara, bai', tijarah, fulk, kaal and wazan, dan saiyr. Dalam Hunter (2014) menyebut bahawa Al-Quran banyak sekali menggunakan metafora bisnes, namun tidak disenarai secara terperinci ayat-ayat tersebut.

Ketika bertemu dengan buku The CommercialTheological Terms in The Koran, penulis merasakan inilah rujukan paling lengkap tentang apa Al-Quran kata tentang bisnes. Buku ini merupakan disertasi PhD Charles Cutler Torrey di Universiti Strasburg, diterbitkan oleh E. J. Brill, Leiden pada tahun 1892. Buku ini boleh didapati dalam format pdf melalui laman sesawang http://menadoc.bibliothek.uni-halle. $\mathrm{de} / \mathrm{ssg} /$ content/titleinfo/453114.

Walaupun kupasan buku lazimnya terhadap buku-buku terbitan terkini, kandungan disertasi ini yang menganalisa secara terperinci ayatayat Al-Quran tentang bisnes begitu menarik minat penulis.

\section{Kandungan Buku}

Buku ini dibahagikan kepada tiga bahagian. Seperti buku-buku lain, bahagian pertama merupakan pendahuluan. Bagi sarjana Orientalis yang mengkaji Islam dan mahir akan kandungan Al-Quran seperti Torrey, adalah satu fakta yang tidak asing bahawa istilahistilah berkaitan agama atau teologi dalam Al-Quran mengguna ungkapan-ungkapan dari dunia bisnes. Kepelbagaian istilah tersebut dan kekerapan ianya disebut di dalam AlQuran mendorong Torrey untuk menghimpun, menyusun dan mengkelas ayat-ayat berkenaan dengan harapan akan lebih jelas tentang konsep ajaran agama Islam yang dibawa oleh Nabi Muhammad (s.a.w).

\section{Bahagian I}

Melalui analisa Torrey terhadap ayat-ayat AlQuran berkaitan bisnes, beliau mendapati ianya berlaku dalam dua bentuk. Bentuk pertama ialah ayat-ayat yang menceritakan tentang dunia bisnes sebenar dan kedua, ayat-ayat yang menggunakan istilah-istilah dunia bisnes untuk menerangkan perkara-perkara berkaitan teologi Islam. Dan fokus kajian $\mathrm{PhD}$ beliau sebenarnya adalah istilah-istilah bisnes yang digunakan untuk menerangkan teologi Islam. Kerana itulah beliau menggunakan "Commercial-Theological Terms" dalam Al-Quran.

Pada bahagian I, Torrey hanya memperkatakan tentang ayat-ayat Al-Quran yang membicarakan bisnes sebenar. Al-Quran mengandungi sangat banyak ayat-ayat berkaitan bisnes dan perdagangan sebenar, merangkumi pelbagai 
subjek. Torrey telah menyusun ayat-ayat Alquran tersebut mengikut subjek-subjeknya. Dalam Surah 106 Quraysh, menceritakan tentang perdagangan yang dilakukan oleh kafilah Quraysh Mekah di musim sejuk ke selatan Semenanjung Tanah Arab (Yaman) dan di musim panas ke utara (Syria). Apa yang boleh difahami dari surah tersebut ialah aktiviti perdagangan pasti akan melibatkan perjalanan yang jauh, melepasi sempadan, merentasi benua, dan dalam konteks hari ini, bisnes dan perdagangan itu bersifat global. Turut mempunyai nada yang sama adalah ayat-ayat seperti 16:112, dan 34:14, 17, 18.

Beberapa tempat pula menceritakan tentang kesibukan hidup seorang pedagang seperti dalam Al Quran (62:9-11), (16:7,14). Binatang dan kapal sebagai alat pengangkutan barang dagangan pada ayat 16:7, 14. Bintang-bintang sebagai penunjuk jalan semasa dalam perjalanan melakukan perdagangan Al Quran (16:16). Disebut tentang kapal-kapal yang belayar untuk tujuan perdagangan sebagai tanda kekuasaan Allah pada Al Quran (2:164) dan (14:32). Selain ayat-tersebut terdapat lebih 10 ayat yang menyebut kapal yang belayar sebagai rahmat Allah yang besar, Al Quran (16:14), (17:68), (22:64), (23: 22), (30:45), (31:30), (35:13), (40: 80), (43:11), (45: 11).
Al-Quran juga menyebut bahawa perdagangan merupakan pekerjaan yang sangat menarik berbanding pekerjaan lain yang boleh menyebabkan manusia lalai dari urusan agama seperti pada Al Quran (24:37), (62:9), dan (9:24). Juga ayat tentang pengharaman riba pada Al Quran (2:282). Dan perkara yang tidak disangka ialah bila mana bisnes dibenarkan semasa Haji. Ini merupakan satu bukti jelas bahawa agama Islam memberi penekanan dan mengiktiraf keperluan bisnes dalam kehidupan manusia, boleh merujuk Al Quran (2:194).

Akhir sekali Torrey menyenaraikan Al-Quran melarang kecurangan semasa melakukan transaksi bisnes seperti ayat-ayat (6:153), (17:37), (55:7, 8), (57:25), (12:59,88), (7:83), $(11: 85,86),(26: 181,183)$ dan (83:1-9). Demikianlah banyaknya ayat-ayat Al-Quran berkaitan bisnes sebenar.

\section{Bahagian II}

Bila menganalisa ayat-ayat Al-Quran yang mengandungi istilah-istilah dalam dunia bisnes yang digunakan untuk menceritakan tentang teologi Islam, Torrey mendapati ianya berlaku lebih banyak dan lebih kerap. Sana-sini dalam Al-Quran menerangkan hubungan antara manusia dengan Tuhan, tentang hari kiamat,

Jadual 1: Senarai kata dasar istilah bisnes untuk menerang teologi Islam yang dijumpai Torrey dalam Al-Quran. Sumber Torrey(1892)

\begin{tabular}{|c|c|c|c|c|c|}
\hline Kategori & $\begin{array}{l}\text { Perhitungan/hisab: takaran } \\
\text { dan ukuran }\end{array}$ & Bayaran; Upah & $\begin{array}{l}\text { Kerugian; } \\
\text { Penipuan }\end{array}$ & $\begin{array}{c}\text { Jualbeli; } \\
\text { Keuntungan }\end{array}$ & $\begin{array}{l}\text { Pinjaman; Jaminan/ } \\
\text { Cagaran }\end{array}$ \\
\hline \multirow{6}{*}{ Istilah dasar } & حسب & جزى & خسر & شرى & قرض \\
\hline & حصى & ثوب & - & بيع & أسلف \\
\hline & - & وفى & بخس & تجر & - \\
\hline & وزن & اجر & ظلم & ثمن & رهن \\
\hline & ثقل & - & ألت & - & \\
\hline & & كسب & نقص & ربح & \\
\hline
\end{tabular}


alam akhirat dalam nada bisnes.

Torrey telah menemukan sebanyak 22 kata dasar istilah bisnes, berlaku sebanyak kira-kira 370 kali dalam Al-Quran. Dari 50 surah pertama AlQuran, hanya empat surah tidak mengandungi istilah-istilah tersebut iaitu surah 1, 43, 44, dan 50. Torrey juga mendapati penggunaan istilahistilah tersebut bukan sekadar diulang-ulang, sebaliknya menunjukkan kepelbagaian dari segi bentuk(terbitan dari kata dasar) dan dari segi aplikasi teologi. Dan istilah-istilah ini menurut Torrey adalah perkataan asli orang Arab, bukan istilah pinjaman dari bangsa lain seperti Yahudi. Kewujudan begitu banyak istilah-istilah bisnes dalam Al-Quran seolah-olah keseluruhan AlQuran itu berkata-kata dengan nada bisnes.

Kini, beliau tidak lagi memasukkan istilahistilah yang digunakan dalam Quran untuk menceritakan tentang bisnes sebenar. Istilahistilah bisnes teologi ini telah dikumpul, dibahagi kepada 5 kategori berikut: perhitungan/ hisab; takaran dan ukuran, pembayaran dan upah, kerugian dan penipuan, jualbeli dan keuntungan, pinjaman dan jaminan/cagaran. Istilah-istilah dasar ini wujud dalam pelbagai bentuk terbitan dalam ayat-ayat Quran, di mana jumlah kesemuanya sebanyak 370 ayat. Jadual 1 menyenaraikan kesemua istilah-istilah dasar yang telah ditemui Torrey.

Torrey telah menyenaraikan kesemua ayatayat Quran yang mengandungi istilah-istilah dasar dalam jadual 1 di atas termasuk istilahistilah terbitan darinya. Hanya beberapa contoh disertakan di sini kerana banyaknya ayat-ayat tersebut.

Sebagai contoh dengan mengambil perkataan hasaba(حسب), diterjemah mengira. Dalam AlQuran wujud dalam bentuk terbitan seperti hisab(حساب), hasib(حاسب). Hisab suatu istilah yang lazim digunakan untuk perkiraan untung dan rugi dalam dunia bisnes, muncul di beberapa tempat dalam al-Quran. Salah satunya ialah nama bagi Hari Kiamat iaitu (يوم الحساب), ketika perhitungan terhadap segala perbuatan manusia di akhirat dilakukan dengan sangat cepat (سريع (الحساب). Sementara istilah hasib diterjemahkan sebagai yang pembuat perhitungan/penghitung, dimaksud ialah Tuhan yang akan menghitung segala perbuatan manusia. Dari 99 Asmaul Husna, المحصى dan adalah termasuk antaranya.

Secara ringkasnya, bahagian II ini menyenaraikan secara terperinci ayat-ayat Al-Quran yang dipanggil Torrey "Commercial-Theological Terms” yang berjumlah hampir 370 ayat.

\section{Bahagian III}

Pada bahagian III buku ini, Torrey mengkaji masa berlakunya istilah-istilah tersebut. Taburan bilangan istilah-istilah tersebut adalah jelas sekata dari surah yang mula turun sehinggalah surah akhir. Tiada satu pun istilah-istilah tersebut berlaku pada satu tempoh tertentu, jadi kewujudan setiap istilah-istilah tersebut tidak dapat dijangka bila ia berlaku.

Tetapi diteliti dari segi kategori istilah-istilah tersebut, Torrey mendapati terdapat perbezaan yang jelas. Istilah-istilah dalam kategori Perhitungan/hisab; takaran dan ukuran, seperti

kerap muncul pada ayatayat Quran yang turun di Mekah. Istilah seperti pula muncul pada zaman الخاسرون,اجر Islam di Madinah. Istilah seperti muncul pada zaman hujung di Mekah.

Menariknya bila mana Torrey telah menulis dalam satu perenggan teologi Islam dengan nada bisnes seperti dijemahkan berikut:

"Hubungan antara Tuhan dan manusia benarbenar bersifat komersial. Allah adalah saudagar yang paling ideal. Setiap sesuatu di alam semesta termasuk dalam perhitunganNya. Setiap perkara 
dikira, setiap sesuatu diukur. Buku rekod dan neraca adalah alat utama sistemNya, dan Dia adalah teladan dalam menjalankan urusniaga yang paling jujur. Kehidupan adalah satu perniagaan, sama untung atau rugi. Mereka yang melakukan kebaikan atau kejahatan, akan mendapat bayaran, kekadang di dunia ini lagi. Sesetengah hutang akan diluputkan, kerana Allah bukanlah pemiutang yang terlalu berkira. Orang-orang Islam membuat pinjaman dari Allah; membayar pendahuluan untuk mendapat syurga; menjual jiwa mereka kepadaNya, satu urusniaga yang tidak akan rugi. Orang tidak beriman pula menjual kebenaran Tuhan dengan harga yang murah, dan mereka adalah orang yang muflis. Setiap jiwa adalah cagaran untuk hutang yang telah dibuat. Pada hari kebangkitan, Allah akan mengadakan perhitungan akhir dengan semua manusia. Perbuatan mereka akan dibaca dari buku akaun amal, ditimbang dengan neraca; setiap jiwa akan dibayar tepat mengikut apa yang dihutang darinya, tiada sesiapa akan dizalimi. Orang yang beriman dan tidak beriman menerima upah mereka. Orang Islam(mereka yang dijanji bayaran berganda di atas perbuatan baik) akan menerima lebih banyak ganjaran istimewa."

Penggunaan istilah-istilah dan frasa-frasa dunia bisnes untuk menerang setiap aspek kehidupan, diulang pula berkali-kali, bagi Torrey ia adalah satu gambaran kukuh dan jelas bahawa semangat bisnes itu penting dalam konsep ajaran Islam. Penggunaan istilah-istilah bisnes untuk menerang teologi Islam sangat bertepatan dengan ciri-ciri dan konteks masyarakat Arab pada ketika itu. Masyarakat Arab ketika itu rata-rata mereka adalah terdiri dari golongan pedagang, dan kota Mekah dan Madinah pula adalah pusat perdagangan yang makmur. Bagi Torrey pendekatan untuk menerang teologi Islam dengan nada bisness adalah praktikal, mudah dan logik, bersesuaian dengan konteks. Maka bagi Torrey juga, teologi Islam adalah teologi yang paling mudah dan paling logik berbanding teologi agama lain.

\section{Al-Quran Edisi Flugel}

Di dalam buku ini, Torrey ada menyatakan beliau merujuk Al-Quran edisi Flugel. Flugel adalah seorang orientalis yang sengaja ingin mengubah Al-Quran (Al-Azami, 2003). Penulis telah merujuk ayat-ayat yang disenarai oleh Torrey menggunakan terjemahan Al-Quran oleh Abdullah Yusuf Ali(1994) dan mendapati ayat-ayat tersebut adalah betul. Cuma terdapat beberapa ayat yang dari segi nombor ayat berbeza sedikit kerana perbezaan kaedah pernomboran yang digunakan. Contohnya ayat tentang kapal-kapal belayar di lautan adalah salah satu tanda kebesaran Allah, mengikut Torrey ayat tersebut adalah Al Quran (2:159), tetapi penulis merujuk terjemahan Al-Quran (2:164). Apapun, pembaca perlu merujuk AlQuran untuk mengesahkan kebenaran ayat-ayat Al-Quran yang disenaraikan.

\section{Analogi Dalam Quran}

Apa yang dinamakan Torrey sebagai "Commercial-Theological Term" itu adalah satu bentuk analogi dalam Quran. Analogi dan metafora adalah biasa dalam Quran (Khairul Hasni, A. K., Norazah, M. N., Zanaton, H.I., dan Norhapizah, M. B. (t.t.) 2016), (Kashaniha, Z., Mirbagheri, S. M., dan Babashah, F., 2005) dan (Ahmad Abdel Tawwab, 2014). Keduaduanya adalah kaedah yang digunakan untuk menerangkan konsep-konsep yang sukar untuk difahami atau dibayangkan kepada bentuk yang lebih mudah difaham dan dapat digambarkan. Konsep hubungan manusia dengan Tuhan, sama dengan konsep sebuah bisnes, ada untung rugi. Maka Allah (s.w.t) menggunakan analogi dunia bisnes kerana aktiviti bisnes bukan sahaja sangat dekat dengan masyarakat Arab, malah semua manusia yang ada keperluan hidup pasti tidak boleh tidak akan mendapatkan keperluan melalui transaksi aktiviti bisnes. 


\section{Kritikan}

Helmidedi (2008) mengkritik buku ini pertama sekali kerana Charles C. Torrey adalah seorang Orientalis. Beliau mempertikaikan apakah yang dimaksudkan oleh Torrey dengan "CommercialTheological Term" dan metodologi yang digunanya untuk menafsir ayat-ayat yang disifatkan sebagai "Commercial-Theological". Bagi Helmidedi (2008), Torrey banyak menyimpang dari makna asal ketika menafsir ayat-ayat yang dinamakan "CommercialTheological" dan mempunyai kepentingan tertentu menyebabkan tafsirannya menjadi sempit dan mengenepikan konsep-konsep lain dalam Al-Quran.

Bagi Prof. Muhammad Mohar Ali di dalam buku beliau bertajuk The Qur'an and The Orientalists, Charles C. Torrey adalah penyokong kepada apa yang dipanggil sebagai Jewish Foundation of Islam. Buku The Commercial-Theological Terms in The Koran ini telah menyebabkan beberapa orientalis lain hanya mengukur kemajuan sosio-ekonomi masyarakat Islam dari aspek bisnes dan perdagangan sahaja, sedangkan dalam Al-Quran, ayat-ayat berkaitan pertanian juga tidak kurang banyaknya. Kehidupan dunia ini diumpamakan sebagai ladang untuk bercucuk tanam di mana hasilnya akan dituai di akhirat. Di antara kebesaran Allah adalah menurunkan hujan yang mana bumi yang kontang akan menjadi subur dan dapat menumbuhkan tanam-tanaman dan buahbuahan. Syurga digambar mempunyai pohonpohon buah-buahan yang rasanya sedap dan sungai-sungai yang mengalir. Maknanya di sini ialah Islam tidak hanya melihat bisnes sebagai satu pekerjaan yang penting, tetapi pertanian juga suatu bidang yang perlu dimajukan oleh orang Islam.

\section{Kesimpulan}

Jika ingin mencari ayat-ayat Al-Quran berkaitan dengan bisnes, buku The CommercialTheological Terms in The Koran dapat memberi senarai yang sangat terperinci. Terdapat 2 bentuk ayat Al-Quran yang membicarakan pasal bisnes. Pertama ialah ayat-ayat yang menceritakan tentang dunia bisnes sebenar dan kedua ialah penggunaan istilah-istilah bisnes untuk menerang teologi Islam. Walaupun buku ini mendapat kritikan dari sarjana Islam kerana ia ditulis oleh seorang orientalis berbangsa Yahudi, yang sememangnya diketahui mempunyai niat yang tidak baik terhadap Islam, tetapi penulis berpendapat, analisa ayat-ayat bisnes dalam buku ini adalah teliti, cuma mungkin tafsiran Torrey terhadap ayat-ayat tersebut tidak tepat kerana mungkin dipengaruhi oleh agenda orientalisma. Penulis lebih kepada ingin mengetahui ayat-ayat Al-Quran yang berkaitan bisnes dan bukan untuk menafsir maksud ayatayat tersebut. Kewujudan istilah-istilah atau ayat-ayat berkaitan bisnes yang sangat banyak di dalam Al-Quran menunjukkan bahawa ajaran Islam adalah sangat dekat bisnes dan mengiktiraf bisnes sebagai satu kerjaya penting untuk maslahah ummah.

\section{Penghargaan}

Penulis ingin merakamkan setinggi-tinggi penghargaan kepada Universiti Tun Hussein Onn Malaysia di atas geran penyelidikan STG U127 yang membolehkan artikel ini ditulis.

\section{Rujukan}

Abdullah, Yusuf ‘A. (1994). The Holy Qur'an: Text and Translation. Kuala Lumpur: Islamic Book Trust.

Al-Azami, M. M. (2003). The History of Quran Text: From Revealation to Compilation A Comparative Study With The Old and New Testaments. UK Islamic Academy.

Ahmad Abdel Tawwab, S. E. (2014). A Cognitive Metaphorical Analysis of Selected Verses in The Holy Quran. International Journal of English Linguistic, Vol. 4, No. 6.

Helmidedi, N. (2008). Istilah-Istilah Komersial Teologis Dalam Al-Qur'an : Studi Pemikiran 
Charles C. Torrey Dalam Buku The CommercialTheological Terms in The Koran. Atas talian http://digilib.uin-suka.ac.id/1001/ Diakses pada 3hb Ogos 2016

Hunter, M (2014). Entrepreneurship As A Means To Create Islamic Economy. Economics, Management \& Financial Markets, 9(1), 75.

Kashaniha, Z., Mirbagheri, S. M., dan Babashah, F. (2015). The Role of Quran Analogies to Understand Great Divine Teachings. Bulletin of Georgian National Academy of Sciences, 9(2).

Khairul Hasni, A. K., Norazah, M. N., Zanaton, H.I., \& Norhapizah, M. B. (n.d.). Atas Talian www.academia.edu/8477950/Analogy_in_ Quran Diakses pada 3hb Ogos 2016

Malahayati, S. (2010). Rahasia Sukses Bisnis Rasulullah. Yogyakarta: Great! Publisher.

Mohammad Mohar, A. (2004). The Quran and The Orientalists : An Examination of Their Main Theories and Assumptions. Jami'yat 'Ihyaa' Minhaj Al-Sunnah, Suffolk, England.

Mohammad Shafi (2000). Business and Commercial in The Qur'an. Dar al Islam Teachers' Institute Alumni News Letter

Torrey, Charles C. (1892). The CommercialTheological Terms in The Koran. Leyden: E. J. Brill. 